\title{
Ao leitor, as advertências
}

\author{
Janine Resende Rocha ${ }^{1}$
}

RESUMO: Neste artigo pretende-se analisar os prefácios escritos por Machado de Assis para seus romances mediante a comparação com as figurações narrativas do leitor.

ABSTRACT: In this article we intend to analyze the prefaces written by Machado de Assis for his novels. In order to do so, we shall compare them with the narrative figurations of the reader.

PALAVRAS-CHAVE: Prefácios; Leitor; Modernidade; Machado de Assis

KEYWORDS: Prefaces; Reader; Modernity; Machado de Assis

Um bom prefácio tem de ser, ao mesmo tempo,

a raiz e o quadrado do livro.

(Friedrich Schlegel, fragmento 08 do Lyceum)

O prefácio - dotado de nomes variados, entre eles prólogo, apresentação, advertência, nota - é um gênero singular, instância do limiar, da passagem, que, de acordo com João Barrento, mais do que o "texto que precede", deve ser visto como o "texto que acompanha" (BARRENTO, 2000, p. 10). Definidos de maneira genérica, sem que façamos distinções entre uma modalidade literária e outra crítica, os prefácios evidenciam a dimensão institucional da literatura e projetam uma orientação de leitura, isto é, pretendem "explicar por que e como se deve ler" (JOUVE, 2002, p. 67).

${ }^{1}$ Mestre em Estudos Literários pela Faculdade de Letras da Universidade Federal de Minas Gerais (UFMG), onde desenvolveu a dissertação intitulada "Limites do sentido: hermenêutica literária e o papel do leitor na contemporaneidade”. Contato: janine_rocha@hotmail.com 
Ainda que os prefácios apontem para o modo como a literatura estimula uma rede de comentários e análises, no caso dos prefácios literários eles podem aspirar a uma espécie de programação da recepção, como se, dessa maneira, os equívocos de leitura pudessem ser evitados. Vemos nesses prefácios uma estratégia retórica que, junto à pretensa validação de uma intenção autoral e de um guia de leitura, eventualmente cumpre um resultado contrário ao pretendido se o leitor verificar como pode haver diferença entre o que se afirma nos prefácios e o que acontece durante seu próprio ato de leitura. Diante desse quadro, aventamos que essa estratégia nutre-se, antes de mais nada, de uma preocupação com o leitor.

A posição lateral do prefácio escrito pelo crítico decorre de ser ele a apresentação a um texto de outro autor, escrita ensaística tergiversante cuja natureza é a da cumplicidade entre o texto do prefácio e o prefaciado. No caso do prefácio literário, temos uma congruência autoral e uma interação entre a verve criadora e a crítica, sem que seja necessariamente projetada uma relação de cumplicidade do autor para com o leitor. Essa autoria coincidente gera a curiosidade quanto às motivações que justificam um tipo especial de prefácio: o escrito pelo próprio autor.

Vale pensar, assim, qual relação o prefácio mantém com a respectiva obra, como ele oferece uma consciência reflexiva da escrita literária ou, para falarmos junto com Jorge Luis Borges em "Prólogo de prólogos", como ele acaba por expor uma estética, amparando, assim, uma forma indireta de critica $^{2}$. A se pontuar especificamente o romance moderno, talvez seja válido supor que esse gênero foi acompanhado inicialmente por prefácios, caminho para formação dos leitores, por ser um gênero sem teoria até a Idade Moderna 3 .

A conciliação da atividade de cunho literário com a de cunho crítico pelos escritores é uma das características da modernidade. Segundo Leyla Perrone-Moisés:

\footnotetext{
2 Ver BORGES. Prólogo de prólogos, p.13-14.

3 Ver BRANDÃO. A invenção do romance, p.30.
} 
Esse exercício particular da crítica, que é a crítica literária, se inscreve num contexto filosófico maior, de profanização da esfera dos valores, de valorização da subjetividade, de perda de respeito pelas autoridades legiferantes e concomitante reivindicação do livre exame e do livre-arbitrio. (PERRONE-MOISÉS, 1998, p. 10)

Essa conciliação, derivada da abolição de referências normativas e de valores fixos que ocorre com o romantismo, cria um canal através do qual o escritor corrobora seus preceitos e sua atividade literária. Ainda nas palavras de Perrone-Moisés: "A crítica dos escritores não visa simplesmente auxiliar e orientar o leitor (finalidade da crítica institucional), mas visa principalmente estabelecer critérios para nortear uma ação: sua própria escrita (...). Nesse sentido, é uma crítica que confirma e cria valores" (PERRONE-MOISÉS,p. 11).

Os prefácios que os autores escrevem para seus textos figuram como um espaço que não é exatamente correspondente à crítica a que se refere Perrone-Moisés, mas que vai ao seu encontro. Neles os autores congraçam princípios que orientaram a escrita das respectivas obras, como William Wordsworth manifesta no prefácio às Baladas líricas: o poeta o escreve movido pelo propósito de empreender uma "defesa sistemática da teoria que presidiu à sua criação" (WORDSWORTH, 1987, p. 169). Assim, os prefácios acentuam a individualidade autoral, determinante, como já observado, para a concepção moderna de literatura.

Destacamos os prefácios - ou advertências - que acompanham grande parte das edições dos romances de Machado de Assis. Em alguns desses prefácios, Machado demonstra a preocupação com a recepção crítica a sua obra, preocupação que segue rente à avaliação feita pelo escritor da sua produção literária. Contudo, a se julgar pelos prefácios dos romances, essa preocupação revela-se decrescente ao longo das suas publicações.

Potencialmente, a atenção com o leitor fomenta o questionamento dos processos através dos quais a literatura condiciona o sentido. Ou seja, a pergunta pelo leitor aponta para a complexidade do enunciado literário na medida em que o sentido ressalta: 1 . o gesto de escrita pelo 
autor; 2. a configuração textual; 3. o estatuto do ficcional, isto é, do referencial criado pela literatura; 4. o ato da leitura. Na obra de Machado de Assis, esses elementos recebem um destaque proeminente, e uma das maneiras de analisá-los pode ser através dos prefácios.

A importância decrescente conferida por Machado ao leitor nas advertências aos romances - que, segundo se observa, diz respeito especialmente ao leitor crítico - parece se confirmar no entrecho das narrativas, como Hélio de Seixas Guimarães argumenta no estudo Os leitores de Machado de Assis. Estimulado, sobretudo, pela teoria de Wolfgang Iser, Guimarães sublinha nos romances machadianos as relações entre narrador e leitor, no âmbito ficcional, e entre escritor e público empírico, no âmbito histórico. O crítico defende que a escassez do público alfabetizado, evidenciada por meio da divulgação de um censo em 1876, teria afetado a forma com a qual Machado desenha a relação entre narradores e leitores. Por isso, segundo a hipótese defendida por Guimarães, desde as Memórias póstumas, os romances acentuam a precariedade da relação entre narrador e leitor, razão pela qual os leitores ganham um espaço cada vez menor em suas páginas.

$\mathrm{Na}$ medida em que a obra do escritor caminha para a maturidade, percurso que imprime lacunas e omissões narrativas a que designamos como negatividade, verificamos um descuido performativo com o leitor. Ou seja, na medida em que a negatividade presente na obra machadiana passa a demandar mais o empenho do leitor, o autor faz um aceno hirto para o leitor ou finge ignorá-lo.

A se julgar literalmente as advertências aos primeiros romances, encontramos um auto-retrato do escritor, complementado com as advertências redigidas para as edições subsequentes dos mesmos. A advertência à primeira edição de Ressurreição mostra um escritor inseguro e humilde ao experimentar um novo gênero, um escritor expectante do comentário da crítica, por entendê-lo como uma oportunidade de aperfeiçoamento. Temos aqui uma visão da crítica contraposta à imagem do crítico narrada por Brás Cubas nas suas Memórias póstumas. No capítulo intitulado "O bibliômano", o narrador 
cogita suprimir o capitulo anterior: segundo ele, “(...) entre outros motivos, há [ali], nas últimas linhas, uma frase muito parecida com despropósito, e eu não quero dar pasto à crítica do futuro" (ASSIS, 1959, p. 488). Na sequência, Cubas perfila a imagem desse crítico:

Olhai: daqui a setenta anos, um sujeito magro, amarelo, grisalho, que não ama nenhuma outra coisa além dos livros, inclina-se sobre a página anterior, a ver se lhe descobre o despropósito; lê, relê, treslê, desengonça as palavras, saca uma sílaba, depois outra, mais outra, e as restantes, examina-as por dentro e por fora, por todos os lados, contra a luz, espaneja-as, esfrega-as no joelho, lava-as, e nada; não acha o despropósito. (...)

O pior é o despropósito. Lá continua o homem inclinado sobre a página com uma lente no olho direito, todo entregue à nobre e áspera função de decifrar o despropósito. Já prometeu a si mesmo escrever uma breve memória, na qual relate o achado do livro e a descoberta da sublimidade, se a houver por baixo daquela frase obscura. Ao cabo, não descobre nada e contenta-se com a posse. Fecha o livro, mira-o, remira-o, chega-se à janela e mostra-o ao sol. Um exemplar único! (ASSIS, 1959, p. 488)

A comparação dessa imagem com a subserviência com a qual Machado se refere à crítica no prefácio de Ressurreição potencializa um sistema interpretativo demarcado pelas duas fases do autor. Ao contrário da imagem do crítico proposta por Brás Cubas, na advertência à primeira edição de Ressurreição Machado demonstra uma confiança respeitosa na crítica, pois ela teria o mérito de decidir a "qualidade" da obra apresentada pelo autor. Já o crítico esboçado pelo defunto autor (ASSIS, 1959, p. 415) recebe contornos sarcásticos pelos quais se depreende o exercício da crítica literária a partir de um atributo inócuo. O crítico seria um leitor despreparado para entender os "enigmas" do texto literário, restando-lhe apenas um fetiche livresco.

Como vemos no retrato do crítico feito por Cubas, o exercício da crítica literária projeta-se sobre o propósito de o crítico decifrar o texto ou descobrir o enigma dele emanado. Esse propósito, que acaba por sublinhar a vontade de se recuperar a intenção autoral - e, em contrapartida, encolhe a liberdade do leitor —, não parece, contudo, ser estimulado por Cubas no prefácio que assina. Nele, o defunto autor 
(ASSIS, 1959, p. 415) frisa a independência da obra perante as possíveis "dicas" do autor:

Mas eu ainda espero angariar as simpatias da opinião, e o primeiro remédio é fugir a um prólogo explícito e longo. O melhor prólogo é o que contém menos coisas, ou o que as diz de um jeito obscuro e truncado. Conseguintemente, evito contar o processo extraordinário que empreguei na composição destas Memórias, trabalhadas cá no outro mundo. Seria curioso, mas nimiamente extenso, e aliás desnecessário ao entendimento da obra. A obra em si mesma é tudo: se te agradar, fino leitor, pago-me da tarefa; se não te agradar, pago-te com um piparote, e adeus (ASSIS, 1959, p. 413; grifos nossos).

Ao iluminar a obra, Cubas sinaliza que ela suscita entendimentos diversos, fato que implode o alcance efetivo de um programa de leitura ditado pelo autor. Em outras palavras, Cubas parece questionar plataformas que influenciem o leitor, na medida em que o defunto autor (ASSIS, 1959, p. 415) privilegia a obra, e não as pretensões do "autor".

Paradoxalmente, através do reconhecimento da obscuridade da obra e da recusa a um caminho autoexplicativo - isto é, ao transpor os parâmetros da negatividade -, Machado realça o papel do leitor e a critica literária. Conforme Guimarães afirma:

Uma das mudanças mais notáveis de Iaiá Garcia para as Memórias póstumas tem a ver com o tratamento dispensado pelos narradores aos leitores e com o nivel de exigência de leitura e interpretação a que estes, os leitores, são submetidos pelos romances da chamada segunda fase. (GUIMARÃES, 2004, p. 35)

Essa alteração quanto à interpretação, isto é, quanto à expectativa do autor ao pensar no sentido encabeçado pelo leitor, estaria anunciada de antemão nos prefácios. Ao deixar de explicar suas pretensões narrativas, Machado se furta a instruir a recepção, escrevendo prefácios que mais parecem antiprefácios.

A convencionada "segunda fase" dos romances machadianos enfatiza, então, como a abertura de sentido propiciada pelos parâmetros da negatividade torna o papel do leitor mais luminoso. Porém, como conciliar o inacabamento do texto, pressuposto pela ideia da negatividade, com o preceito segundo a qual os limites do leitor são 
outorgados pelo próprio texto? Essa dúvida revela a dificuldade em se conciliar o fato de o texto literário ter como característica a inexauribilidade do sentido e, ao mesmo tempo, limitar a atuação do leitor, isto é, regular sua leitura.

Podemos reformular essa dificuldade nos seguintes termos: num nível abstrato-teórico, a inexauribilidade do sentido é uma prerrogativa obrigatória para a estética literária moderna - uma vez que essa estética problematiza a origem e a totalidade do sentido porém, na sua concretude, a leitura e a interpretação ocorrem sob parâmetros limitadores. Sendo assim, parece haver certa idealização da interpretação quando se afirma que a legibilidade do texto literário guarda um caráter infindável, como o faz Silvina Rodrigues Lopes:

Quando lemos um poema podemos dizer que, para além de atendermos à ordem sequencial dos seus elementos, somos solicitados por hipóteses de associação e de confronto que rompem essa ordem. Temos sempre presente a composição como um jogo que desconhece as suas regras e que nos leva a reinventá-las na dependência das circunstâncias da leitura, efêmeras, por definição. Podemos dizer que, por mais reduzido em termos de extensão que seja o poema, a sua interpretação é infinita, o seu limite é ilimitação. É por isso que o poema não é a soma de um plural de significados, mas sim um lugar de disseminação dos significados. (LOPES, 2005, p. 133)

Ainda que o argumento acima mencione apenas o texto poético, podemos estendê-lo ao texto ficcional. Apesar das diferenças entre esses regimes textuais — inclusive do ponto de vista da doação de sentido —, a "disseminação dos significados" é válida para ambos os gêneros literários.

Segundo Iser, a interpretação é "um esforço cognitivo que busca produzir sentido a partir daquilo a que fomos expostos" (ISER in ROCHA (org.), 1999, p. 132). Ao reforçar que o sentido é estimulado pelo texto, essa definição explicita, por outro lado, que o sentido exige um esforço do leitor, isto é, que há limites circunscritos à sua esfera. Além de sublinhar os limites do leitor, o "esforço cognitivo" mencionado pela definição implica também um apelo à linguagem, pois os domínios do sentido e da interpretação são erguidos via linguagem. Em outras 
palavras, podemos dizer que tanto o sentido quanto a interpretação obrigam a tradução do texto literário em outros - ou novos - termos, como conjura o conto "Pierre Menard, autor do Quixote", de Borges, ao ilustrar como o ato da leitura é também um ato de reescrita do texto, sem que haja uma polaridade entre um ato e outro. E reescrever o texto significa assumir a incompletude e o afastamento da objetividade como marcas.

No ensaio "A interpretação da obra literária”, Alfredo Bosi explica a conjunção entre interpretação e tradução:

\begin{abstract}
Interpres chamavam os romanos àquele que servia de agente intermediário entre as partes em litígio. Com o tempo, interpres assumiu também a função de tradutor: o que transporta o significado da sua forma original para outra; de um código primeiro para um código segundo; o que pretende dizer a mesma mensagem, mas de modo diferente. A interpretação opera nessa consciência intervalar, e ambiciona traduzir fielmente o mesmo, servindo-se dialeticamente do outro. O outro é o discurso próprio da literatura (BOSI, 1988, p. 277; grifo do autor).
\end{abstract}

Da citação, interessa-nos destacar a correspondência aludida entre interpretação e tradução. Porém, discordamos de Bosi na medida em que o autor promove o intérprete como agente capaz de veicular, de forma coincidente, a mensagem do texto lido no texto reescrito.

Acreditamos, ao contrário, que tal correspondência operacionaliza não uma repetição, mas uma différance - na acepção de Jacques Derrida -, que questiona a origem e a essência. Em termos iserianos, podemos dizer que, em respeito à assimetria entre texto e leitor, a leitura deve ser pensada como um ato de estranhamento ou de interrupção, que obriga a distinção entre a expressão literária e a da leitura - crítica ou não. A correspondência entre interpretação e tradução acaba por enfatizar a textualidade da própria crítica; e, através desse aspecto, observa-se que o papel do leitor concorre para a exploração do sentido via linguagem. 


\section{Referências bibliográficas}

ASSIS, Machado de. Obra completa, v. I. Rio de Janeiro: José Aguilar, 1959.

BARRENTO, João. "Pela porta dos afetos." In BARRENTO, João. Umbrais: o pequeno livro dos prefácios. Lisboa: Cotovia, 2000, p. 9-21. BORGES, Jorge Luis. "Prólogo de prólogos." In BORGES, Jorge Luis. Obras completas, v.4. Barcelona: Emecé Editores, 1996, p. 13-14. BOSI, Alfredo. “A interpretação da obra literária.” In BOSI, Alfredo. Céu, inferno: ensaios de crítica literária e ideológica. São Paulo: Ática, 1988, p. 274-287.

BRANDÃO, Jacyntho Lins. A invenção do romance: narrativa e mimese no romance grego. Brasília: Editora Universidade de Brasília, 2005.

GUIMARÃES, Hélio de Seixas. Os leitores de Machado de Assis: o romance machadiano e o público de literatura no século 19. São Paulo: Nankin Editorial; EdUSP, 2004.

JOUVE, Vincent. A leitura. Trad. Brigitte Hervor. São Paulo: UNESP, 2002.

LOPES, Silvina Rodrigues. "Literatura e hipertexto." In LOPES, Silvina Rodrigues. A anomalia poética. Lisboa: Vendaval, 2005, p. 131-154.

PERRONE-MOISÉS, Leyla. "Introdução." In PERRONE-MOISÉS, Leyla. Altas literaturas: escolha e valor na obra critica de escritores modernos. São Paulo: Companhia das Letras, 1998, p. 9-17.

ROCHA, João Cezar de Castro (org.). Teoria da ficção: indagações à obra de Wolfgang Iser. Trad. Bluma Waddington Vilar e João Cezar de Castro Rocha. Rio de Janeiro: EdUERJ, 1999.

WORDSWORTH, William. "Prefácio às Baladas líricas." In LOBO, Luiza (trad., sel. e notas). Teorias poéticas do Romantismo. Rio de Janeiro: UFRJ; Porto Alegre: Mercado Aberto, 1987, p. 169-187. 